\title{
Development of The Stem Career Interest Scale for High School Students
}

\author{
Esra Kizilay \\ Erciyes University, Turkey \\ Havva Yamak \\ Nusret Kavak \\ Gazi University, Turkey
}

Doi:10.19044/ejes.v7no3a4 URL:http://dx.doi.org/10.19044/ejes.v7no3a4

\begin{abstract}
In this study, it is aimed to develop a scale to be used to determine the STEM career interest of high school students. Because, when STEM career studies in the literature are examined, the lack of STEM career scale for high school students is remarkable. In this research, developing STEM Career Interest Scale for high school students is important for literature. The scale development principles specified by DeVellis were taken into consideration during the development of the scale. 25-items STEM career interest scale trial form was applied to 462 high school students in their 2016-2017 academic year in Kayseri in Turkey. Exploratory Factor Analysis (EFA) and Confirmatory Factor Analysis (CFA) was performed for the construct validity through the data set obtained from the study group. SPSS 22 and AMOS 24 package programs were used to analyze the data. According to the results of Exploratory Factor Analysis (EFA), it was determined that the scale consisted of 20 items and 3 sub-dimensions. Scale sub-dimensions were named as: interest, self-efficacy, outcome expectations. It was determined that the threefactor structure related to the scale explained $71 \%$ of the total variance. The Cronbach alpha coefficient was 0.96 for the whole scale. STEM Career Interest Scale developed for high school students can be used in experimental studies or descriptive studies. Validity and reliability studies can be performed by applying the scale to different education levels and it can be used in the studies.
\end{abstract}

Keywords: STEM career, STEM career interest, social career cognitive theory. 


\section{Introduction}

The 21st century is the beginning of the digital age. At this age, technology has improved and knowledge has increased (Beers, n.d.). The advances in technology and the increase in knowledge have caused some changes in the society. With this change, individuals required some skills to be successful in our century and society (Akgunduz, 2016). These skills are generally called 21 st century skills.

21 st century skills are classified in different ways. Partnership for $21 \mathrm{st}$ Century Learning has divided its 21 st century skills into three groups as follows; learning and innovation skills, information-media and technology skills, life, and career skills (P21, 2016).

In the report published by the World Economic Forum, 16 skills were specified. These skills are as follows; Literacy, arithmetic, information, and communication technology literacy, scientific literacy, financial literacy, cultural and citizenship literacy, critical thinking / problem solving, creativity, communication, cooperation, curiosity, initiative, resilience, adaptation, leadership, social, and cultural awareness (World Economic Forum, 2015).

21st century skills are collected under four main titles by The Assessment and Teaching of 21st Century Skills (ATC21S). These skills are as follows; ways of thinking (creativity and innovation, critical thinking, problem solving, learning to learn, metacognition ...), ways of working (communication, collaboration), working tools (literacy, information, and communication technology literacy), life in the world (citizenship, life and career, individual responsibility, social responsibility) (ATC21S, n.d.; Griffin \& Care, 2015).

When different classifications of 21 st century skills are examined, it is seen that creativity and innovation, critical thinking and problem solving, communication, cooperation, information management, effective use of technology, career and life skills, and cultural awareness skills are common in most of them (Beers, n.d.). Schools today need to provide training to acquire these skills. These schools should aim for students who are researching, learning and entrepreneurs. Schools should pay attention to individual differences, contain flexible lessons, and include a system that enables the interaction of multiple disciplines. Therefore, today education programs are changing from one discipline-based education with a teaching that includes several disciplines. The first examples of this can be seen in STAEM (Science, Technology, Art, Engineering and Mathematics) education (Yavuz, 2016).

STEM education, which today focuses on the interdisciplinary integration of science, technology, engineering and mathematics disciplines, was introduced by the National Science Foundation (NSF) as an acronym in the 1990s (Bybee, 2013; Dugger, 2010). STEM education has many goals for students. These goals are aimed at providing students with 21 st century skills 
and getting students ready for the needs of the age. For this reason, the aims of STEM education for students include STEM literacy, 21st century skills, preparation for STEM workforce, interest and participation, and the ability to link STEM disciplines. Some results of STEM education for these purposes are as follows; 21st century skills, STEM related career choice, STEM interest (Honey et al., 2014).

\section{Relevant Literature}

Today, it is very important for students focusing on STEM fields. Especially professionals in the field of STEM are indispensable for the innovation and economic growth of countries and today's needs (Carnevale et al., n.d.). Considering the needs of the future, it is thought that STEM professionals will be important and new STEM professions will emerge. For this reason, many countries focus on increasing the number of students who prefer STEM fields and the number of STEM professionals.

Targets related to STEM fields are included in the STEM Education Strategic Plan of North Carolina (USA). The goals included in the plan include the following; Increasing student interest in STEM fields, increasing the proportion of students graduating from STEM programs (Public Schools of North Carolina, n.d.). In the "National STEM School Education Strategy 2016-2026" report approved by the Austrian Ministry of Education in 2015, the main topics determined for national action include the increase of STEM participation of students (Education Council, 2015). The Netherlands has developed a STEM education strategy since 2004 aimed at promoting science and technology education to increase the talented employees of the future. This strategy aimed to overcome the shortage of scientists and engineers in the country (Kearney, 2016). In Ireland, research projects are carried out in schools for students to choose their science, engineering and technology career areas (European Commission/EACEA/Eurydice, 2010). In Turkey, the Ministry of National Education (MONE), even where the strategic plan in the STEM teaching strategies, there are some studies about STEM. The first pilot studies related to STEM began to be implemented in Kayseri in Turkey. Through the applications, it is aimed to increase the interest of students in mathematics and science in schools (Kayseri Provincial Directorate of National Education, 2013). In the following years, MONE and various universities introduced strategies and actions related to STEM.

The activities of countries regarding STEM education and career have shown their effect in the studies in the literature. In the literature, researches related to STEM career have been conducted. In the study of Sadler, Sonnert, Hazari and Tai (2012), how students' STEM career interests changed during high school was examined. It was determined that men show interest in engineering fields, women show interest in health and medicine. In the 
research conducted by Christensen, Knezek and Tyler-Wood (2015), the factors affecting students' STEM careers and STEM interest were investigated. It was determined that a student's self-motivation, parent support, high quality motivating teacher factors were effective on students' STEM careers. In the study of Brown, Concannon, Marx, Donaldson, and Black (2016), the interests of middle school students in STEM, their beliefs in STEM, and possible gender differences in STEM self-efficacy were investigated. In a study carried out by Korkut-Owen and Mutlu (2016), the number of students' placement in higher education between 1999-2003 was examined and their tendency to choose STEM fields was evaluated. As a result of the evaluation, it was determined that women generally prefer natural sciences, mathematics and statistics, and men generally prefer computer and engineering. In a study conducted by Yerdelen, Kahraman and Tas (2016), low socio-economic secondary school students' STEM career interests and attitudes towards STEM fields were investigated. As a result of the research, it was determined that the students had positive emotions in having a STEM career. Bolds (2017) examined STEM career development of high school students in his doctoral thesis. Within the framework of Social Cognitive Career Theory, it was determined that students' mathematics and science selfefficacy, outcome expectation and interest were important determinants on STEM career intent and STEM field selection. In a study carried out by Christensen and Knezek (2017), they examined the relationship of middle school students to STEM and their intentions to pursue a career in STEM. In the study, it was concluded that male students have a higher intention to pursue a career in STEM fields and show more interest in STEM fields. In a study conducted by Sellami, El-Kassem, Al-Qassass and El-Rakeb (2017), the factors that help estimate students' interests in the STEM field were investigated. Korkut Owen and Eraslan Capan (2018) revealed the reasons for secondary school students to think and not think about choosing STEM areas. In the literature, it was seen that there are some scale development studies related to STEM careers.

Tyler-Wood, Knezek and Christensen (2010) created two measurement tools that can be used to evaluate students' STEM disciplines and career perceptions. Kier, Blanchard, Osborne and Albert (2013), a scale of STEM career interest was developed in a study. The scale was applied in the sample of secondary school students. Social cognitive career theory constituted the theoretical basis of the scale. Oh, Jia, Lorentson and LaBanca (2013) developed a measurement tool that measures the education and career interests of high school students in STEM. Guzey, Harwell and Moore (2014), a tool was developed to measure students' (4-6th grade) attitudes towards STEM and STEM careers. Milner, Horan and Tracey (2014) have developed measurement tools that can be used to determine students' STEM interests and 
self-efficacy. Unfried, Faber, Stanhope and Wiebe (2015) have developed two measurement tools suitable for two samples (grades 4-5 and grades 6-12) that measure students' attitudes towards STEM and their interest in STEM careers. Koyunlu Unlu, Dokme and Unlu (2016) in their study, they adapted a STEM career interest scale in the relevant literature to Turkish in the sample of secondary school students.

\section{Research Focus and Research Aim}

When STEM career studies in the literature are examined, the lack of STEM career scale for high school students is remarkable. In this research, developing STEM Career Interest Scale for high school students is important for literature.

In this research, it was aimed to develop a scale that can be used to measure the STEM career interest of high school students.

\section{Research Methodology \\ Participants}

The group in which the results in a study are valid is called the universe. The part of the universe where data is collected is called a sample (Buyukozturk, Kilic Cakmak, Akgun, Karadeniz \& Demirel, 2012). In this research, STEM career interest of students will be investigated. For this reason, the universe of the research has been determined as the age range of 14-16 years, which is the age of orientation towards the profession or career (Telman, 2006). Because the first years of the 14-18 age range is the period when individuals recognize their own interests and abilities (Cakir, 2011). Therefore, students in high schools in Kayseri in Turkey were chosen as the research universe. 462 students determined by the proportional stratified sampling method were selected. These students formed the sample of the research (Johnson \& Christensen, 2014). The number of samples in the study was determined according to the formula recommended by Cochran (1962; as cited in Balci, 2011). According to the formula, the size of the sample to be selected from the research universe should be at least 381 .

The scale was applied in the academic year of 2016-2017. The scales have been implemented in four high schools in Kayseri in Turkey. A total of 462 students participated in the study. Information about the students is given in Table 1. 
Table 1

Distribution of students according to schools and gender

\begin{tabular}{lllll}
\hline Schools & Grade & Male & Female & Total \\
\hline High School 1 & 9 & 43 & 7 & 50 \\
& 10 & 28 & 22 & 50 \\
& 11 & 17 & - & 17 \\
& 12 & 21 & 19 & 40 \\
& Total & 109 & 48 & 157 \\
\hline High School 2 & 9 & 8 & - & 8 \\
& 10 & 8 & 2 & 10 \\
& 11 & 5 & 3 & 8 \\
& 12 & 5 & 3 & 8 \\
\hline High School 3 & Total & 26 & 8 & 34 \\
& 9 & 16 & 19 & 35 \\
& 10 & 16 & 24 & 40 \\
& 11 & 10 & 10 & 20 \\
& 12 & 10 & 8 & 18 \\
& Total & 52 & 61 & 113 \\
\hline High School 4 & 9 & 18 & 22 & 40 \\
& 10 & 13 & 27 & 40 \\
& 11 & 19 & 39 & 58 \\
& 12 & 9 & 11 & 20 \\
& Total & 59 & 99 & 158 \\
\hline Total & & 246 & 216 & 462 \\
\hline
\end{tabular}

Instrument and procedures

In this research, the STEM career interest scale was developed for high school students. The scale development principles specified by DeVellis (2014) were taken into consideration during the development of the scale (Figure 1). 


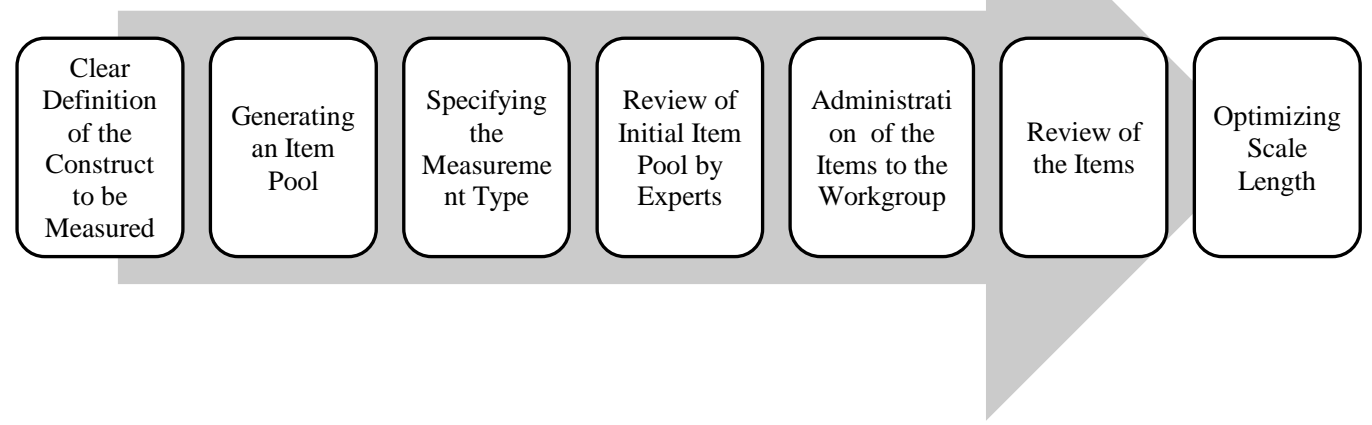

Fig. 1

Scale development principles (DeVellis, 2014)

\section{Step 1: Clear definition of the construct to be measured}

When developing a scale, the relevant literature should be examined to determine the structural features of the examined case and to base the scale on a theory (DeVellis, 2014; Ozdamar, 2016). For this reason, in the research, the theoretical framework of the scale was determined by examining the studies related to STEM careers. As a result of the examinations, it was decided to base the STEM Career Interest Scale on Social Cognitive Career Theory (SCCT) (Lent, Brown \& Hackett, 1994). Because, although SCCT has many common features with other theories, it is a newer theory (Unsal, 2014). This theory was explained by Lent in 1994. According to the researchers, career development is divided into three models; model of the development of interest, career choice model and performance model. There is a connection between self-efficacy, outcome expectation and interest in the model of development of interest (Lent et al., 1994). While developing STEM Career Interest Scale, these three concepts were determined as sub-dimensions.

\section{Step 2: Generating an Item Pool}

In the study, a pool of 38 items was prepared for the STEM Career Interest Scale.

\section{Step 3: Specifying the Measurement Type}

In this study, the answers given by high school students to STEM Career Interest Scale indicate the level of approval of the students. For this reason, the Likert scale type, which is an answer option used to show the level of approval in the research, was used (DeVellis, 2014). 


\section{Step 4: Review of Initial Item Pool by Experts}

Expert evaluation form was prepared to present the item pool to the expert opinion. In the form, there are options and suggestions about whether each item is suitable or not. This form has been submitted to the opinion of six experts. Information about the experts is given in Table 2.

Table 2

Information about the experts

\begin{tabular}{ll}
\hline Degree of the Experts & Expert's fields of study \\
\hline Professor & STEM education, technology of education \\
Assoc. Prof. & STEM education, technology of education \\
Assoc. Prof. & STEM education \\
Asst. Prof. & STEM education \\
Asst. Prof. & Assessment and evaluation, statistics \\
Dr. & Self-efficacy \\
\hline
\end{tabular}

In accordance with the opinions of experts, each item in the scale was re-examined and corrected. A scale containing 25 positive items was prepared.

\section{Step 5: Review of the Items and Giving the Appropriate Form}

Examples of the 25 items in the scale and the resources used when writing the items are presented in Table 3 . Some items were written by researchers.

Table 3

Examples of items in the item pool and resources used in writing items

\begin{tabular}{|c|c|c|c|c|c|c|c|}
\hline No & Items & 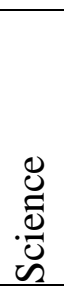 & 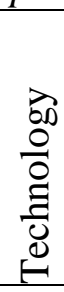 & 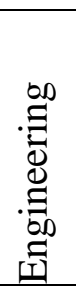 & 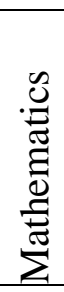 & 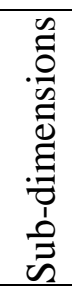 & Resources \\
\hline 1 & & & & & & & $\begin{array}{l}\text { George, 2012; Maskan, } \\
2010\end{array}$ \\
\hline 2 & & & & & & & Ekici, 2009 \\
\hline 3 & & & & & & & Ekici, 2009 \\
\hline 4 & 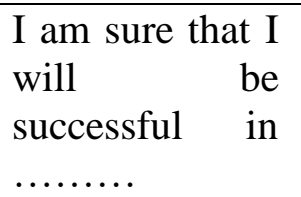 & & & & & 导 & $\begin{array}{l}\text { Brown et al., 2016; } \\
\text { George, 2012; Kier et al., } \\
2013\end{array}$ \\
\hline$\frac{5}{6}$ & & & & & & $\begin{array}{l}0 \\
\stackrel{I}{D} \\
\end{array}$ & \\
\hline
\end{tabular}




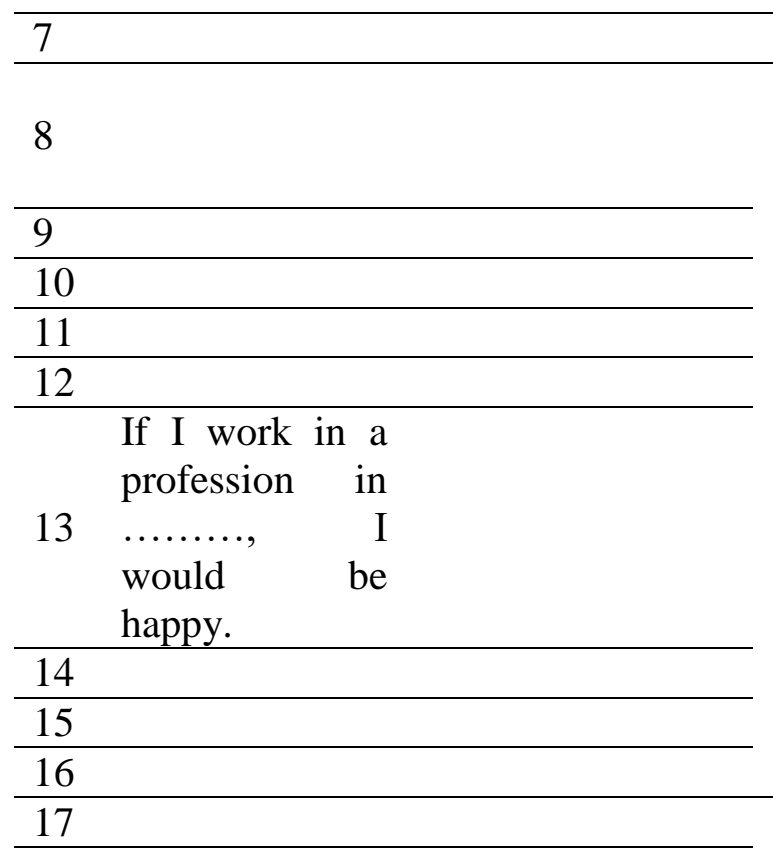

18

\begin{tabular}{lll}
\hline 19 & & \\
\hline & Professions in \\
20 & $\ldots \ldots$ & interest \\
& me. \\
\hline 21 & \\
\hline 22 & \\
\hline 23 & \\
\hline
\end{tabular}

Christensen et al., 2014; Christensen \& Knezek, 2017

Kier et al., 2013

Christensen et al., 2014

Kier et al., 2013

Christensen et al., 2014;

Christensen \& Knezek, 2017; Ertas Kilic \& Keles, 2017; Kier et al., 2013; Kurbanoglu \& Arslan, 2015; Oh et al., 2013

Brown et al., 2016

Kier et al., 2013

Christensen et al., 2014; Christensen \& Knezek, 2017; Ertas Kilic \& Keles, 2017; Kier et al., 2013; Kurbanoglu \& $\vec{*}$ Arslan, 2015; Oh et al., 过 
For the items in the scale, students were asked to answer the gaps by filling them with science, technology, engineering and mathematics, respectively. Then, the scores that students gave to science, mathematics, engineering and technology for each item were summed up and divided into four. In this way, the scores of the students in each item vary between 1-5. There are reasons why the word STEM is not used when writing items instead of science, technology, engineering and mathematics disciplines. One of the reasons is the lack of STEM higher education department in Turkey. Also, STEM education in Turkey is not very old. Therefore, STEM may not make sense for any of the students. Some experts also suggested that the word STEM should not be used.

\section{Data analysis}

The scale was finalized by making exploratory factor analysis to STEM Career Interest Scale. Then, confirmatory factor analysis, reliability analysis, item variances, the $27 \%$ difference between upper and lower groups were calculated. SPSS 22 and AMOS 24 package programs were used to analyze the data.

\section{Results}

\section{Exploratory factor analysis}

Kaiser-Meyer-Olkin (KMO) value of the scale was found to be .96 . Bartlett's test of the scale was found to be significant $(p<.05)$.

Items 9 and 10 were removed from the scale because of overlapping. After removing the item, varimax techniques, was used. The overlapping items 8 and 13 were removed from the scale and factor analysis was repeated using "varimax" technique. As a result of the analysis, it was found that all items except item 16 was distributed according to theoretical background. After reviewing this item, it was decided to remove them from the scale. The total variance table explained as a result of factor analysis is given in Table 4.

According to Table 4, the scale consisted of three factors explaining $71 \%$ of the analyzed construct. "Scree Plot" graph of the scale is given in Figure 1. Regarding Figure 1, the number of factors was found to be three. 


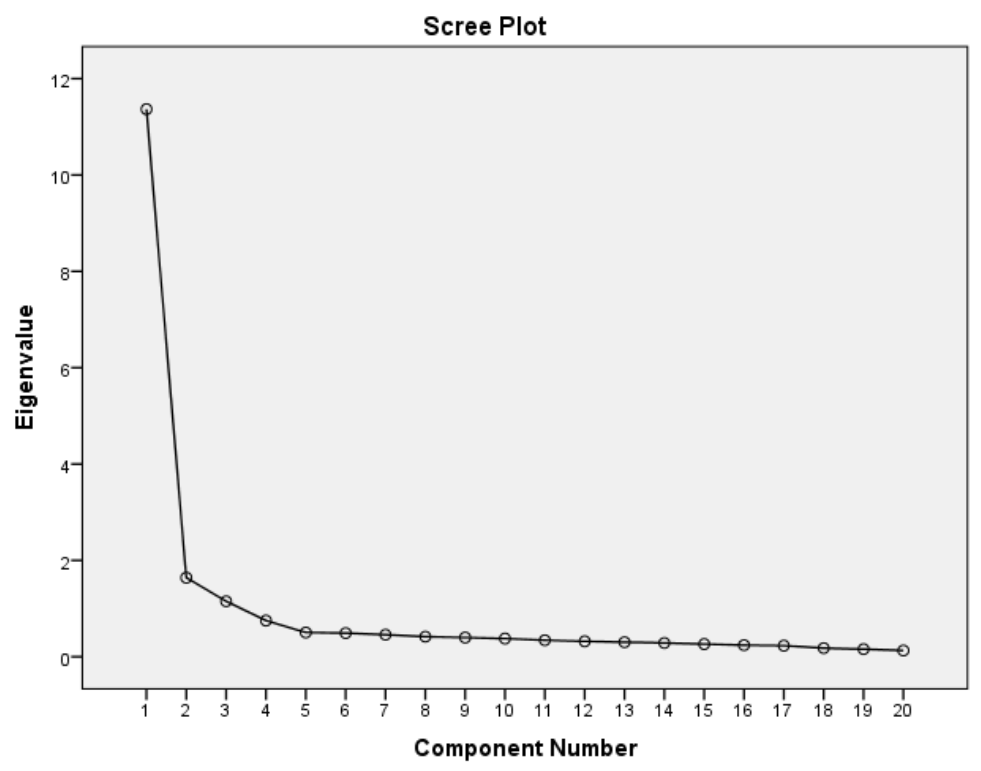

Fig. 2

"Scree Plot" graph of STEM career interest scale

Table 4

STEM career interest scale - Total variance table

\begin{tabular}{llll}
\hline & \multicolumn{2}{l}{ Initial Eigenvalues } \\
\cline { 2 - 4 } Components & Total & Variance Percentage & Cumulative Percentage \\
\hline 1 & 11.366 & 56.83 & 56.83 \\
2 & 1.641 & 8.21 & 65.04 \\
3 & 1.152 & 5.76 & 70.80 \\
4 & .751 & 3.76 & 74.55 \\
5 & .504 & 2.52 & 77.07 \\
6 & .490 & 2.45 & 79.52 \\
7 & .457 & 2.28 & 81.81 \\
8 & .416 & 2.08 & 83.89 \\
9 & .398 & 1.99 & 85.88 \\
10 & .377 & 1.88 & 87.76 \\
11 & .344 & 1.72 & 89.48 \\
12 & .320 & 1.60 & 91.08 \\
13 & .303 & 1.51 & 92.59 \\
14 & .286 & 1.43 & 94.02 \\
15 & .263 & 1.32 & 95.34 \\
16 & .240 & 1.20 & 96.54 \\
17 & .229 & 1.15 & 97.69 \\
18 & .178 & .89 & 98.58
\end{tabular}


According to the results, the scale consists of 20 items, under three sub-dimensions/factors in Table 5.

Factor 1: Interest (Items 17, 18, 19, 20, 21, 22, 23, 24, 25)

Factor 2: Self-efficacy (Items 1, 2, 3, 4, 5, 6, 7)

Factor 3: Outcome expectation (Items 11, 12, 14, 15)

Table 5

Rotated component matrix of STEM career interest scale

\begin{tabular}{|c|c|c|c|}
\hline \multirow{2}{*}{ Items } & \multicolumn{3}{|c|}{ Factors } \\
\hline & $\overline{1}$ & 2 & 3 \\
\hline$\overline{\text { kar22 }}$ & .80 & & \\
\hline kar21 & .79 & & \\
\hline kar23 & .75 & & \\
\hline kar24 & .73 & & \\
\hline kar20 & .73 & & \\
\hline kar25 & .72 & & \\
\hline kar19 & .70 & & \\
\hline kar18 & .67 & & \\
\hline kar17 & .66 & & \\
\hline kar2 & & .80 & \\
\hline kar4 & & .80 & \\
\hline kar1 & & .80 & \\
\hline kar5 & & .71 & \\
\hline kar6 & & .70 & \\
\hline kar3 & & .69 & \\
\hline kar7 & & .67 & \\
\hline kar15 & & & .85 \\
\hline kar12 & & & .76 \\
\hline kar14 & & & .71 \\
\hline kar11 & & & .69 \\
\hline
\end{tabular}

\section{Confirmatory factor analysis}

In the confirmatory factor analysis, $\chi^{2} / \mathrm{sd}$ value was found to be 4.06 . CFI value in the analysis was calculated as .93 in the analysis. RMSEA value was found to be .08. The confirmatory factor analysis is given in Figure 2.

The factor loads ranged between $.77-.88$ for interest sub-dimension; $.70-.88$ for self-efficacy sub-dimension; $.75-.83$ for outcome expectation subdimension. Since $p<.05$ for these values, the items were appropriately assigned 
to the factors. The following strong relationships were revealed between the factors.

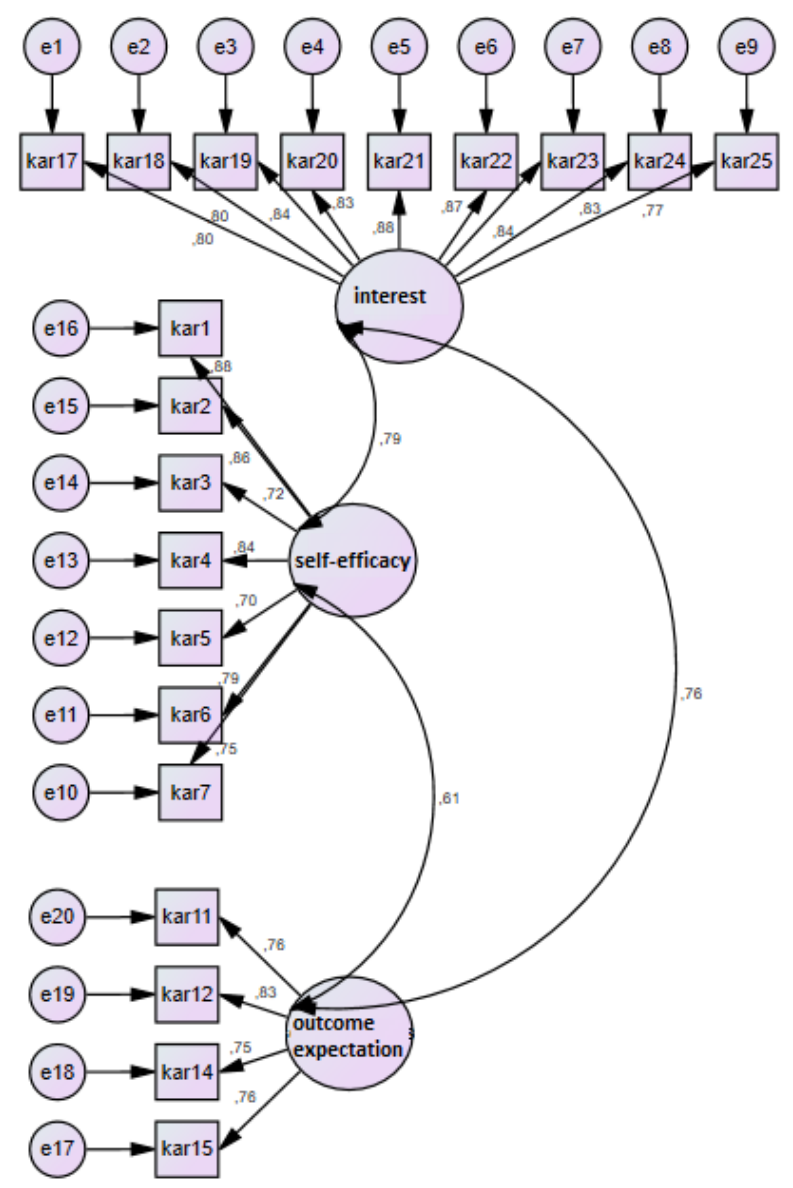

Fig. 3

STEM career interest scale - Path diagram

\section{Reliability analysis}

The Cronbach Alpha coefficients are given in Table 6. STEM Career Interest Scale has high reliability. 
Table 6

Cronbach's alpha coefficients of the STEM Career Interest Scale

\begin{tabular}{|c|c|c|}
\hline Sub-dimensions & $\begin{array}{l}\text { Number of } \\
\text { Items }\end{array}$ & $\begin{array}{l}\text { Cronbach Alpha coefficient } \\
(\alpha)\end{array}$ \\
\hline Self-efficacy & 7 & .92 \\
\hline $\begin{array}{l}\text { Outcome } \\
\text { expectation }\end{array}$ & 4 & .86 \\
\hline Interest & 9 & .95 \\
\hline Scale & 20 & .96 \\
\hline
\end{tabular}

\section{Item variances}

The variances of the items of the STEM Career Interest Scale are given in Table 7. According to Table 7, the variance statistics for the items are higher than .73 .

Table 7

STEM Career Interest Scale - Item variances

\begin{tabular}{llll}
\hline Items & Variance Statistics & Items & Variance Statistics \\
\hline kar1 & .78 & kar15 & .93 \\
kar2 & .73 & kar17 & .77 \\
kar3 & .79 & kar18 & .82 \\
kar4 & .83 & kar19 & .91 \\
kar5 & .84 & kar20 & .83 \\
kar6 & .89 & kar21 & .89 \\
kar7 & .90 & kar22 & .96 \\
kar11 & .98 & kar23 & .91 \\
kar12 & .94 & kar24 & .83 \\
kar14 & .84 & kar25 & .85 \\
\hline
\end{tabular}

\section{Difference between the Lower and Upper Groups of $\mathbf{2 7 \%}$}

T-test results of the scale between the lower and upper groups are given in Table 8.

Table 8

Independent groups t-test results between lower and upper students

\begin{tabular}{lllllll}
\hline Groups & N & Mean & Ss & $\boldsymbol{t}$ & $\boldsymbol{d} \boldsymbol{f}$ & $\boldsymbol{p}$ \\
\hline Lower Group & 125 & 49.34 & 10.95 & \multirow{2}{*}{28.531} & 202.187 & .0001 \\
Upper Group & 125 & 81.87 & 6.53 & & & \\
\hline
\end{tabular}

As $\mathrm{p}<.05$ in Table 8, there is a significant difference between the lower and upper. The mean score of the upper group was 81.87 . The mean score of the 
lower group was 49.34. The scale can measure the distinction between students with low and high scores.

As a result of the factor analyzes, item analyzes and reliability analyzes described above, a valid and reliable 20-item and three-factor STEM Career Interest Scale was developed.

\section{Discussion}

In the research, STEM Career Interest Scale was developed for high school students in Turkey. While developing the scale in the research, the scale development steps suggested by DeVellis (2014) were followed. These steps were followed in many scales developed in the literature.

The first step in developing the scale is "Clear Definition of the Construct to be Measured". In the research, it was decided to base the STEM Career Interest Scale on SCCT (Lent et al., 1994). Because the same theoretical background has been included in many studies in the literature. The theoretical foundation of the STEM career interest scale developed by Kier et al. (2013) for secondary school students is based on the SCCT (Lent et al.,1994). Moakler and Kim (2014) included at SCCT as a conceptual framework in their study in STEM career choice. In a study by Nugent, Barker, Welch, Grandgenett, Wu \& Nelson (2015), SCCT was included as a theoretical basis. Bahar and Adiguzel (2016) based the SCCT on the theoretical background of their research in which high school students examine their STEM career choice. Sahin, Ekmekci and Waxman (2017) also determined this theory as a theoretical framework in their studies in which high school students researched future STEM career plans. In addition, although SCCT has many common features with other theories, it is a newer theory (Unsal, 2014).

SCCT was explained by Lent in 1994. There is a connection between self-efficacy, outcome expectation and interest in the model of development of interest (Lent et al., 1994). While developing STEM Career Interest Scale, these three concepts were determined as sub-dimensions. Self-efficacy is about how individuals perceive their own abilities. Self-efficacy is the total belief of individuals regarding a particular field of activity (Koc, 2003; Unsal, 2014). For this reason, items such as "I am sure that I will be successful in ......." were included in the preparation of items in the sub-dimension of self-efficacy. Outcome expectation includes material and moral rewards that individuals will achieve at the end of a behavior (Unsal, 2014). For this reason, the items in the outcome expectation sub-dimension included expressions such as "If I work in a profession in ........, I would be happy". Interest refers to things that are important to the individual in the current time period (Telman, 2006). Therefore, while preparing items in this sub-dimension, expressions such as "Professions in ..... interest me" were included. 
The scale was finalized by making exploratory factor analysis to STEM Career Interest Scale. Then, confirmatory factor analysis, reliability analysis, item variances, item averages, corrected item total correlations, the $27 \%$ difference between upper and lower groups were calculated.

When developing a measurement tool, factor analysis is used to get information about the structure of the scale (Tavsancil, 2010). This method is used to determine how many factors the items in the draft scales combine and the type of relationship between the factors (Sonmez \& Alacapinar, 2016). For this purpose, factor analysis was conducted.

There are some conditions for starting factor analysis. One of these conditions is that the sample size is sufficient. The general idea in factor analysis is that the sample size of 300 people is sufficient. Or it is enough to reach at least 5 times the number of items (Secer, 2013). In this study, the sample size was limited to 462 people. This number is over 300 and more than 5 times the item pool. Another condition for factor analysis is the KMO value. This value gives information about the adequacy of the sample size. If the KMO value is 0.7 and above, it can be said that the sample size is good. Another condition for factor analysis is Barlett's test. This test is used to determine whether the data come from normal distribution and the value should be meaningful (Can, 2014; Secer, 2013). In the study, the KMO value of the scale was found to be 0.961 and Bartlett's test was found to be significant $(p<.05)$. Based on these results, it was decided that it was appropriate to continue factor analysis.

In factor analysis, the load value of each item in the factor shows how the item is related to the conceptual structure measured by the factor. If the factor load value of an item is low, that item is not related to the structure measured by the factor. According to Sencan (2005), this value should be at least 0.30 . In this study, the limit value for factor load values was determined as 0.30 . After factor analysis, factor load values of the items were examined. As a result of the examination, it was determined that there was no item with a load value below 0.30 . Whether each item is overlapping or not is checked. Since items 9 and 10 are overlapping items, these items have been removed from the scale. Then, varimax technique was used in repeated factor analysis. "Varimax" technique is used to reveal more than one sub-dimension (Sencan, 2005). After the application of this technique, the "rotated component matrix" table was examined and it was determined that there were two contiguous items. Items 8 and 13 were removed from the scale and the varimax technique was used again. As a result of the analysis, it was determined that all items except item 16 fit the theoretical background. Item 16 has been re-evaluated. As a result of the evaluation, it was decided to exclude item 16 from the scale. After the items were removed from the scale, the scale consisted of 20 items. Finally, factor analysis was applied to the scale again by using "varimax" 
technique. After the analysis was applied, it was determined that the scale explained $71 \%$ of the examined structure and consisted of three factors with at least 1 eigenvalue. In a factor analysis, the eigenvalue of each factor must be at least 1 . Factors meeting this condition are named as sub-dimensions. The total variance table alone is not sufficient to determine how many factors a scale consists of. For this reason, the "Scree Plot" graphic can also be examined (Secer, 2013). As a result of all examinations, it was determined that the scale consists of 20 items. The scale consists of interest, outcome expectation and self-efficacy sub-dimensions. When similar scales in the literature are examined, it is seen that the same sub-dimension names are used. In addition, in some studies related to STEM careers, it is seen that the theoretical background is based on SCCT and interest, self-efficacy and outcome expectations (Garriott et al., 2017; Mau et al., 2019; Mohtar et al., 2019; Nugent et al., 2015; Roller et al., 2018; Silva Cardoso et al., 2013).

In this study, confirmatory factor analysis was applied to the scale to examine the accuracy of the structure determined by exploratory factor analysis (Karagoz, 2016). In the analysis results, fit indices and factor loadsregression coefficients were examined. In this research, some fit indices are examined. $\chi 2$ / sd value was found to be 4.064. The acceptable limit value of the $\chi 2 /$ sd value is 5 . A value greater than 5 indicates incompatibility. CFI value was calculated as 0.932 . It is acceptable for the CFI value to be greater than 0.90. In the research, the RMSEA value was found to be 082. It is an acceptable result that this value is less than 0.1 (Ozdamar, 2016). When the fit indexes were examined, it was determined that the scale structure was acceptable. In the research, factor loads of the sub-dimensions of the scale were also examined. Factor loads in the interest sub-dimension ranged between 0.77-0.88. Factor loads in the self-efficacy sub-dimension ranged from 0.70 to 0.88 . The factor loads in the outcome expectation sub-dimension ranged between $0.75-0.83$. Since $p<.05$, it is meaningful that the items are loaded on the factors. In other words, it can be said that the items are loaded correctly on the factors (Karagoz, 2016).

In the study, the reliability coefficient of the scale was calculated. Cronbach Alpha is a method used to determine the reliability of classified and ranked scales (Sonmez \& Alacapinar, 2016). This method is based on the compatibility of the items in one scale. The calculated coefficient must be at least 0.70 (Secer, 2013). In this study, the reliability coefficient of the scale was calculated as 0.96 .

It is important that the items of a scale have high variance. This will show that the people who answered the scale did not answer that item in the same way (DeVellis, 2014). In the study, it was determined that the variance statistic of all items in the scale was greater than 0.728 . 
It is important that the average of the scores on a scale is close to the center of the possible score range (DeVellis, 2014). In this study, item scores are in the range of 1-5. The average of the items is close to 3 .

Items on a scale should be largely related to the community of items outside of it (DeVellis, 2014). This relationship is expressed by the correlation coefficient. The value of the coefficient must be greater than 0.20 (Tavsancil, 2010). Corrected item total correlation of all items in the study is greater than 0.563 .

It is important to examine the discrimination of the scale items between individuals with high and low scores. According to the scale scores, the student with the highest score is ranked from the lowest to the lowest. The difference in score between the top $27 \%$ group and the bottom $27 \%$ group is tested (Tavsancil, 2010). In this study, it can be said that the scale can measure the difference between the students with low and high scores.

\section{Conclusions and Implications}

As a result of this research, STEM Career Interest Scale was developed by the researchers. As a result of exploratory factor analysis, a factor structure that consists of 20 items and 3 factors was formed. The "interest" factor consisted of 9 items; the "self-efficacy" factor consisted of 7 items; the "outcome expectation" factor consisted of 4 items. The determined factor structure of the scale was confirmed by Confirmatory Factor Analysis. The Cronbach's alpha value of the whole scale was 0.96 . It is believed that the scale will contribute to the literature as a valid and reliable measuring scale for determining high school students' interest in STEM career.

STEM Career Interest Scale developed for high school students can be used in experimental studies or descriptive studies. Validity and reliability studies can be performed by applying the scale to different education levels and it can be used in the studies.

\section{Acknowledgements}

This study is part of the first author's doctoral dissertation. All necessary permissions were obtained from the Kayseri Provincial Directorate of National Education before the scale was applied to students. The study was presented as an oral presentation at the 10th International Congress of Educational Research in 2018. 


\section{References:}

1. Akgunduz, D. (2016). Yeni nesil okulda teknoloji entegrasyonu. M. Yavuz (Ed.), In Yeni Nesil Okul "Araştıran Okul" (p. 133-185). Konya: Eğitim Yayınevi.

2. ATC21S (t.y.). Retrieved from http://www.atc21s.org/

3. Bahar, A. \& Adiguzel, T. (2016). Analysis of factors influencing interest in STEM career: Comparison between American and Turkish high school students with high ability. Journal of STEM Education: Innovations and Research, 17(3), 64-69.

4. Balci, A. (2011). Sosyal bilimlerde araştırma: Yöntem, teknik ve ilkeler. Ankara: Pegem Akademi.

5. Beers, S. Z. (n.d.). 21st Century Skills: Preparing Students for THEIR Future.

6. Bolds, T. (2017). A structural and intersectional analysis of high school students' STEM career development using a social cognitive career theory framework. PhD Thesis, Syracuse University, Amerika.

7. Brown, P. L., Concannon, J. P., Marx, D., Donaldson, C. W., \& Black, A. (2016). An examination of middle school students' STEM selfefficacy with relation to interest and perceptions of STEM. Journal of STEM Education: Innovations and Research, 17(3), 27.

8. Buyukozturk, S., Kilic Cakmak, E., Akgun, O. E., Karadeniz, S. \& Demirel, F. (2012). Bilimsel araştırma yöntemleri (13. Baskl). Ankara: Pegem Akademi.

9. Bybee, R. W. (2013). The case for STEM education: Challenges and opportunities. Arlington, Virginia: NSTA Press.

10. Cakir, M. A. (2011). Meslek seçimi, mesleki karar ve mesleki kararsızlık. Ankara: Anı Yayıncilık.

11. Can, A. (2014). SPSS ile bilimsel araştırma sürecinde nicel veri analizi (2. Baskı). Ankara: Pegem Akademi.

12. Carnevale, A. P., Smith, N. \& Melton, M. (n.d.). STEM: science, technology, engineering, mathematics. Washington, D.C.: Georgetown University Center on Education and the Workforce.

13. Christensen, R. \& Knezek, G. (2017). Relationship of middle school student STEM interest to career intent. Journal of Education in Science, Environment and Health, 3(1), 1-13.

14. Christensen, R., Knezek, G. \& Tyler-Wood, T. (2014). Student perceptions of Science, Technology, Engineering and Mathematics (STEM) content and careers. Computers in human behavior, 34, 173186.

15. Christensen, R., Knezek, G. \& Tyler-Wood, T. (2015). A retrospective analysis of STEM career interest among mathematics and science 
academy students. International Journal of Learning, Teaching and Educational Research, 10(1).

16. DeVellis (2014). Ölçek geliştirme ilkeleri. T. Totan (Çev. Ed.), In Ölçek Geliştirme (A. S. Sağkal, Çev.) (p.73-114). Ankara: Nobel.

17. Dugger, W. E. (2010, December). Evolution of STEM in the United States. 6th Biennial International Conference on Technology Education Research, Australia.

18. Education Council (2015). National STEM school education strategy: A comprehensive plan for science, technology, engineering and mathematics education in Australia. Retrieved from http://www.educationcouncil.edu.au/site/DefaultSite/filesystem/ documents/National\%20STEM\%20School\%20Education\%20Strateg y.pdf

19. Ekici, G. (2009). Adaptation of the biology self-efficacy scale to Turkısh. Kastamonu Ĕ̈itim Dergisi, 17(1), 111-124.

20. Ertas Kilic, H. \& Keles, Ö. (2017). Development of the scale of interest in astronomy: Valıdıty and reliability studies. Eğitimde Kuram ve Uygulama, 13(1), 35-54.

21. European Commission/EACEA/Eurydice (2010). Ĕ̈itim çıktılarında cinsiyet farklıliklarl: Avrupa'da alınan tedbirler ve mevcut durum. Eğitim, İşitsel-Görsel Medya ve Kültür Yürütme Ajansı.

22. Garriott, P. O., Hultgren, K. M. \& Frazier, J. (2017). STEM stereotypes and high school students' math/science career goals. Journal of Career Assessment, 25(4), 585-600.

23. George, K. (2012). A STEM scholarship program model to reverse high student attrition. Proceedings of the 2012 ASEE PSW Section Conference, Cal Poly, Amerika.

24. Griffin, P. \& Care, E. (2015). The ATC21S method. P. Griffin \& E. Care (Eds.), In Assessment and Teaching of 21st Century Skills: Methods and Approach (p. 3-33). Dordrecht: Springer.

25. Guzey, S. S., Harwell, M. \& Moore, T. (2014). Development of an instrument to assess attitudes toward science, technology, engineering, and mathematics (STEM). School Science and Mathematics, 114(6), 271-279.

26. Honey, M., Pearson, G. \& Schweingruber, H. (Eds.) (2014). STEM integration in K-12 education: Status, prospects, and an agenda for research. Washington, D.C.:The National Academies Press.

27. Johnson, B. \& Christensen, L. (2014). Nicel, nitel ve karma araştırmalarda örnekleme. S. B. Demir (Çev. Ed.), Eğitim Araştırmaları: Nicel, Nitel ve Karma Yaklaşımlar (İ. Budak \& A. Budak, Çev.) içinde (s. 215-242). Ankara: Eğiten Kitap. 
28. Karagoz, Y. (2016). SPSS 23 ve AMOS 23 uygulamal istatistiksel analizler. Ankara: Nobel.

29. Kayseri Provincial Directorate of National Education (2013). STEM projesi ile bilim adamlart yetiştirilecek. Retrieved from http://kayseri.meb.gov.tr/stem/index.aspx

30. Kayseri Provincial Directorate of National Education (2016). Kayseri Milli Ĕ̈itim Istatistikler: 2015-2016.

31. Kearney, C. (2016). Efforts to increase students' interest in pursuing mathematics, science and technology studies and careers. National measures taken by 30 countries - 2015 Report, European Schoolnet, Brussels.

32. Kier, M. W., Blanchard, M. R., Osborne, J. W. \& Albert, J. L. (2013). The development of the STEM career interest survey (STEMCIS). Research in Science Education, 1-21.

33. Koc, G. (2003). Sosyal öğrenme kuramı. A. Ulusoy (Ed.), In Gelişim ve Öğrenme (p. 207-242). Ankara: Anı Yayıncılık

34. Korkut Owen, F. \& Mutlu, T. (2016). Gender differences on selecting STEM areas in Turkey. Yaşadıkça Eğitim, 30(2), 53-72.

35. Korkut Owen, F. \& Eraslan Capan, B. (2018). Reasons for science, technology, engineering and mathematics selection among high school students. Yaşadıkça Ĕgitim Dergisi, 31(2), 23-40.

36. Koyunlu Unlu, Z., Dokme, I. \& Unlu, V. (2016). Adaptation of the science, technology, engineering, and mathematics career interest survey (STEM-CIS) into Turkish. Eurasian Journal of Educational Research, 63, 21-36.

37. Kurbanoglu, N. İ. \& Arslan, S. (2015). The educational and career interest scale in science, technology, and mathematics: Validity and reliability study. International Journal of Human Sciences, 12(1), 1477-1484.

38. Lent, R. W., Brown, S. D. \& Hackett, G. (1994). Toward a unifying social cognitive theory of career and academic interest, choice, and performance. Journal of Vocational Behavior, 45, 79-122.

39. Maskan, A. (2010). An evaluation of prospective physics and maths teachers' self-efficacy beliefs toward physics. Uludă Üniversitesi Ĕ̈itim Fakültesi Dergisi, 23(1), 31-42.

40. Mau, W. C., Chen, S. J. \& Lin, C. C. (2019). Assessing high school student's STEM career 1nterests using a social cognitive framework. Education Sciences, 9(2), 151.

41. Milner, D. I., Horan, J. J. \& Tracey, T. J. (2014). Development and evaluation of STEM interest and self-efficacy tests. Journal of Career Assessment, 22(4), 642-653. 
42. Moakler, M. W. \& Kim, M. M. (2014). College major choice in STEM: Revisiting confidence and demographic factors. The Career Development Quarterly, 62(2), 128-142.

43. Mohtar, L. E., Halim, L., Rahman, N. A., Maat, S. M., Iksan, Z. H. \& Osman, K. (2019). A model of interest in stem careers among secondary school students. Journal of Baltic Science Education, 18(3), 404-416.

44. Nugent, G., Barker, B., Welch, G., Grandgenett, N., Wu, C. \& Nelson, C. (2015). A model of factors contributing to STEM learning and career orientation, International Journal of Science Education, 37(7), 1067-1088.

45. Oh, Y. J., Jia, Y., Lorentson, M., \& LaBanca, F. (2013). Development of the educational and career interest scale in science, technology, and mathematics for high school students. Journal of science Education and Technology, 22(5), 780-790.

46. Ozdamar, K. (2016). Eğitim, săglık ve davranış bilimlerinde ölçek ve test geliştirme/ yapisal eşitlik modellemesi. Eskişehir: Nisan Kitabevi.

47. P21 (2016). Framework for 21st century learning. Retrieved from http://www.p21.org/storage/documents/docs/P21_framework_0816.p df

48. Public Schools of North Carolina (n.d.). North Carolina's science, technology, engineering, and mathematics (STEM) education strategic plan. Retrieved from http://www.dpi.state.nc.us/docs/stem/overview/education-strategicplan.pdf

49. Roller, S. A., Lampley, S. A., \& Dillihunt, M. L., Benfield, M. P. J. \& Turner, M. F. (2018). Student Attitudes Toward STEM: A Revised Instrument of Social Cognitive Career Theory Constructs (Fundamental). 2018 ASEE Annual Conference \& Exposition.

50. Sadler, P. M., Sonnert, G., Hazari, Z. \& Tai, R. (2012). Stability and volatility of STEM career interest in high school: A gender study. Science education, 96(3), 411-427.

51. Sahin, A., Ekmekci, A. \& Waxman, H. C. (2017). Collective effects of individual, behavioral, and contextual factors on high school students' future STEM career plans. International Journal of Science and Mathematics Education, 1-21.

52. Secer, I. (2013). SPSS ve LISREL ile pratik veri analizi: Analiz ve raporlaştırma. Ankara: Anı Yayıncılık.

53. Sellami, A., El-Kassem, R. C., Al-Qassass, H. B. \& Al-Rakeb, N. A. (2017). A Path Analysis of Student Interest in STEM, with Specific Reference to Qatari Students. EURASIA Journal of Mathematics Science and Technology Education, 13(9), 6045-6067. 
54. Sencan, H. (2005). Sosyal ve davranışsal ölçümlerde güvenilirlik ve geçerlilik. Ankara: Seçkin Yayıncılık.

55. Silva Cardoso, E., Dutta, A., Chiu, C., Johnson, E. T., Kundu, M., \& Chan, F. (2013). Social-cognitive predictors of STEM career interests and goal persistence in college students with disabilities from racial and ethnic minority backgrounds. Rehabilitation Research, Policy, and Education, 27(4), 271-284.

56. Sönmez, V. \& Alacapınar, F. G. (2016). Sosyal bilimlerde ölçme aracı hazırlama. Ankara: Anı Yayıncilık.

57. Tavsancil, E. (2010). Tutumların ölçülmesi ve SPSS ile veri analizi (4. bask1). Ankara: Nobel Yayın Dağıtım.

58. Telman, C. (2006). Başarıya giden yolda meslek seçimi. İstanbul: Epsilon.

59. Tyler-Wood, T., Knezek, G. \& Christensen, R. (2010). Instruments for assessing interest in STEM content and careers. Journal of Technology and Teacher Education, 18(2), 345-368.

60. Unfried, A., Faber, M., Stanhope, D. S. \& Wiebe, E. (2015). The development and validation of a measure of student attitudes toward science, technology, engineering, and math (S-STEM). Journal of Psychoeducational Assessment, 33(7), 622-639.

61. Unsal, P. (2014). Kariyer gelişim kuramları ve kariyer danışmanlığı. Ankara: Nobel.

62. World Economic Forum (2015). New vision for education: Unlocking the potential of technology. Geneva. Retrieved from http://www3.weforum.org/docs/WEFUSA_NewVisionforEducation_ Report2015.pdf

63. Yavuz, M. (2016). "Yeni nesil okul”un kavramsal inşası. M. Yavuz (Ed.), In Yeni Nesil Okul “Araştıran Okul” (p. 3-11). Konya: Eğitim Yayınevi.

64. Yerdelen, S., Kahraman, N. \& Tas, Y. (2016). Low socioeconomic status students' STEM career interest in relation to gender, grade level, and STEM attitude. Journal of Turkish Science Education, 13, 59-74. 